\title{
PREDICTING POTENTIAL EFFECTS OF CLIMATE CHANGE ON BENTHIC SPECIES: CURRENT AND FUTURE DISTRIBUTION OF NATIVE AND NON-NATIVE CHAROPHYTES AND AMPHIPODS
}

\author{
KAIRE TORN, KRISTJAN HERKÜL, ANNELIIS PETERSON \& ÜLO SUURSAAR \\ Estonian Marine Institute, University of Tartu, Estonia
}

\begin{abstract}
The ongoing climate change is expected to affect the distribution and vitality of marine aquatic species through various links and changes in environmental conditions. The aim of the study was to analyse and compare climate change related effects on native and non-native benthic species groups in the Baltic Sea. We analysed the impact of changes on the charophytes (native Chara aspera and non-native Chara connivens) and gammarid amphipods (native Gammarus salinus and non-native Gammarus tigrinus). Currently, C. aspera and G. salinus are the most widespread and frequent species among charophytes and gammarids in NE Baltic Sea. C. connivens has been recorded in single locations in the 1960s, following the continuous enlargement of the distribution area since 2005. G. tigrinus has showed significant occupation success in the region since their first finding in 2003. The random forest modelling method was used to produce current species distribution models and to predict the potential changes of distribution based on future climate scenarios. In the brackish Baltic Sea, species are often living close to their salinity tolerance limits and the decrease in salinity will probably cause profound changes in distribution of both marine and freshwater species. Moreover, the model predictions showed that, probably due to wider salinity and temperature tolerance, the non-native species will gain advantages over native species. Due to climate change, a significant increase of the distribution areas of non-native species is expected to occur on account of the native species. The distribution area of $C$. connivens is predicted to double and G. tigrinus to increase by $15 \%$. Changes in environmental conditions also favour the distribution of native charophyte C. aspera due to the freshwater origin of the species. However, the marine species G. salinus is predicted to lose $65 \%$ of its distribution area.

Keywords: species distribution modelling, ensemble learning, macrovegetation, zoobenthos, global warming, Baltic Sea.
\end{abstract}

\section{INTRODUCTION}

Contemporary climate-related changes have already caused adverse impacts on Earth's environment [1], threatening diversity, stability and functioning of ecosystems [2]. The ongoing global change is predicted to further affect marine environments through various links and processes [3]. The climate change related impacts are among the strongest in the northern areas like the Baltic Sea, where the warming has been faster than the global average (by now $1^{\circ} \mathrm{C}[1]$, [4]) over the last decades [5]. In the Baltic Sea region, evident climatological changes have appeared as an increase in winter and spring air temperatures, increase in water temperature, decrease in seasonal ice extent, increase in precipitation and fresh water runoff, decrease in salinity, and changes in wind speed and storminess [6], [7]. On the other hand, the semi-enclosed, relatively young and brackish water Baltic Sea is highly vulnerable to such stressors, which affect both pelagic and benthic communities [8]. Effect on the distribution and vitality of the populations of both macrovegetation [8], [9] and zoobenthos species [8], [10] has been reported.

The Baltic Sea hosts a mixture of marine, brackish and freshwater species, living often close to their physiological tolerance limits [11]. Therefore, even small changes in abiotic conditions can dramatically affect species distribution and relationships [12]. Warming 
climate and changes in hydrology may either enable or hinder the future distribution of species [8], [13]. Due to wider salinity and temperature tolerance, non-native species are assumed to gain advantages over native species [8], [14]. However, the problem deserves more study, because the tolerance to the changes vary among species [13], [15], [16]. There are also habitat generalists among both native and non-native species [17]. In addition to climate change effects, trophic status of the Baltic Sea can also change in the future as a result of anthropogenic factors (including pollution control measures stipulated by the HELCOM and EU directives) [4], [8]. However, these impacts are not studied in this article.

Using ensemble learning methods, we studied two groups of benthic organisms. Charophytes are one of the most important habitat formers among macrovegetation in the soft-bottom areas in the Baltic Sea [18]. Gammarids are diverse group of amphipod crustaceans which has important role in herbivory, detritus cycle and as a prey for fish [19]. Seven species of charophytes have been found in the Estonian coastal waters [16]. Besides climate change, the problem of alien species is also increasingly important in the Baltic Sea [8]. During current study we analysed the effect of climate change on the geographical distribution of native and non-native charophytes (native Chara aspera and non-native Chara connivens) and gammarid amphipods (native Gammarus salinus and non-native Gammarus tigrinus). The representatives of native species are currently both most widespread and frequent species among charophytes and gammarids in the NE Baltic Sea. First record of $C$. connivens in the Baltic Sea is from the 1850s [20]. Although the species is believed to be introduced to Baltic Sea from western Europa by ballast water of ships [20], the proven origin of the species is remained unclear and species is categorised as cryptic [18]. Chara connivens has been recorded in single locations in the 1960s in the Estonian coastal sea, following the continuous enlargement of distribution area since 2005 [18], [21]. The alien species $G$. tigrinus occurs naturally in North America. The species was introduced to Europe probably in ballast water. First finding in the Baltic Sea was 1975 followed by quick expansion of distribution area [22]. G. tigrinus has showed significant occupation success since the first finding of the species in Estonia in 2003 [22].

The focus species - C. aspera and C. connivens - are of freshwater origin with ability to tolerate brackish conditions. C. aspera can be found at salinity range $0-18, C$. connivens $0-9$ [18], [23]. Six species of gammarid amphipods have been found in the Estonian marine waters [24]. The focus species - G. salinus and G. tigrinus - are considered as euryhaline. G. tigrinus can be found between salinity range $0-25$ [25] while G. salinus is limited by minimum salinity 2 [26].

The main aims of this study were to (1) model the current and future distribution of charophytes and amphipods in the NE Baltic Sea, and (2) to compare the predicted changes in native and non-native species, that reflect the establishment success of the newcomers.

\section{MATERIAL AND METHODS}

\subsection{Study area}

The study was conducted in the Estonian coastal waters in the NE Baltic Sea (Fig. 1). The study area included three major sub-basins of the sea (Baltic Proper, Gulf of Finland and Gulf of Riga) and a small West Estonian Archipelago Sea, which is surrounded by islands and the Estonian mainland. All the sub-basins exhibit considerable gradients in depth, wave exposure and salinity. Salinity exceeds 7 in the westernmost study area while it falls to almost 0 in the inner parts of bays with riverine inflow. The coastal zone is extensively shallow in the 


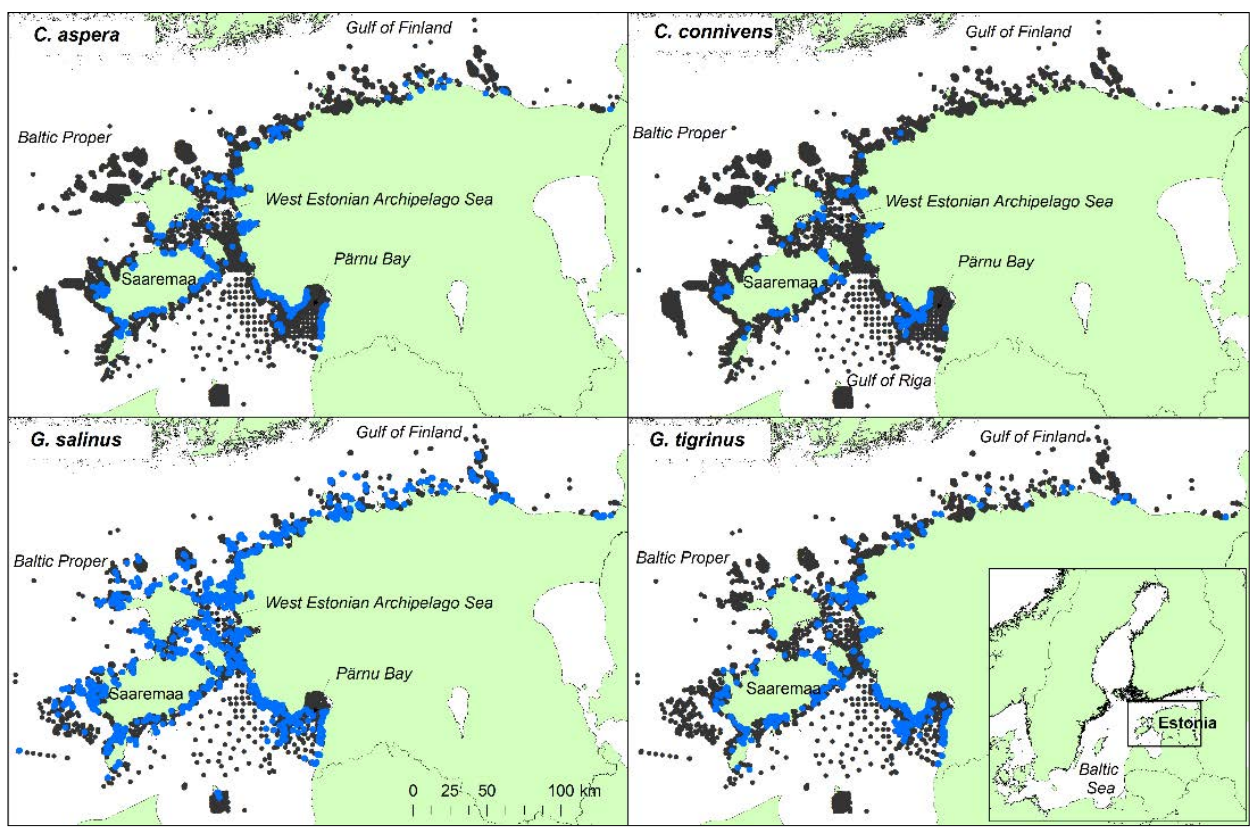

Figure 1: Locations of sampling sites (black dots) and sampling sites where the studied species occurred (blue dots).

western part of the study area while steep coastal slope strongly limits the extent of shallow coastal area in the Gulf of Finland.

\subsection{Benthic data}

To evaluate the temporal dynamics of the native species and the establishment success of the non-native species, a long-term dataset of the Estonian Marine Institute, University of Tartu, from years 1960-2019, was used. Sampling were performed based on species determination by a scuba diver (macrovegetation), in a laboratory based on underwater video recordings (macrovegetation), quantitative samples collected by grab samplers (macrovegetation, zoobenthos) or by scuba divers with a metal frame (macrovegetation, -zoobenthos). In the laboratory, the samples were sorted and all macrobenthic organisms were identified under a microscope. As the amount and location of sampling sites have varied during 1960-2019, mean values of five-year periods were used to assess the frequency of occurrence of the studied species. To illustrate the massive increase in abundance of $G$. tigrinus, the abundance data collected annually from the same site in Pärnu bay was used.

Data from 11,474 macrovegetation sampling sites from years 2005-2015 were used as an input for a mathematical model to predict the occurrence of the charophytes (Fig. 1). The presence-absence data of the species was collected as described in the previous paragraph. Data from 9,987 benthic sampling sites from years 2005-2019 were used as an input for a mathematical model to predict the occurrence of the gammarid amphipods (Fig. 1). Temporal replicates of sampling sites were removed and data only from the most recent sampling event was retained. Geographical coordinates were determined in each sampling site using a handheld GPS device. 


\subsection{Environmental data}

Water depth, wave exposure, salinity, temperature and sediments were used as abiotic environmental variables in the modelling process. All the abiotic data layers were already available as raster layers in the geographical information system (ESRI ArcGIS). Depth data were obtained from the Estonian Maritime Administration. A simplified wave model was used to characterize the wave impact. The wave model incorporates shoreline topography, fetch length and wind data to mimic wave conditions by using empirically derived algorithms [27]. The sediment type (expressed as a value between 0 and 1) described the summed proportion of soft substrate types (mud, clay, sand, gravel) in seabed substrate. Temperature and salinity data both for the present and future conditions originated from the ECHAM5/RCAO general circulation model output [28]. The coupled physicalbiogeochemical model used regionalized data from the ECHAM5 [29] and included the output from the 3D Rossby Centre Atmosphere Ocean model [30]. As the ocean circulation model was three-dimensional, we used the data from bottom layer only.

\subsection{Future climate scenario}

Future climate change scenario included seasonal means of the summer (June to August) and winter (December to February) water temperature and salinity for the period 2070-2099. The future climate scenario based on the A1B emission scenario. The scenario considers the predictions of future developments (technology, economy, demographic change etc.) and emissions of different greenhouse gases, included $\mathrm{CO}_{2}$ [31].

Based on the future climate scenario, the mean salinity is predicted to decrease from 5.5 to 3.7 in the study area. However, the change is not spatially uniform and some areas face a change of up to 3.3 . The mean temperature is predicted to increase from 16.6 to $18.3^{\circ} \mathrm{C}$ in summer and from 1.4 to $4.5^{\circ} \mathrm{C}$ in winter. Likewise, the temperature change is not spatially uniform with maximum change of up to $7.7^{\circ} \mathrm{C}$ in summer and up to $3.9^{\circ} \mathrm{C}$ in winter.

In prescribing the changes in wind conditions, a uniform $10 \%$ increase in annual mean wind speed was used. Due to partly counteraction processes, the global sea-level increase and glacio-isostatic uplift in the Fennoscandian uplift area, the sea-level changes were considered negligible in our study area and were not considered in future modelling. Also, no changes in sediment data were used in the present and future scenario models. For more detailed explanations, see Torn et al. [16].

\subsection{Modelling}

The random forest (RF) modelling method was used to produce current species distribution models and predict the potential changes of distribution based on future climate scenario. Random forests or random decision forests are an ensemble learning method in statistics and machine learning [32], [33]. For more details, see Torn et al. [16] and Peterson et al. [34]. The models were trained using the current climate data (see the previous sections). For future predictions, the values of temperature, salinity and wave exposure based on the future scenarios were entered into the models. Model predictions were calculated to each point in the prediction dataset covering the study area with $100 \mathrm{~m}$ rectangular equispaced grid. The point-wise predictions were converted to GIS georeferenced raster layers. The modelling and conversion to rasters was done in the statistical software $\mathrm{R}$ 3.6.1 [32]. The $\mathrm{R}$ package randomForest [33] was used for RF modelling. 


\section{RESULTS}

\subsection{Current distribution of species}

The distribution range of charophyte $C$. aspera covers practically whole Estonian coastal sea while distribution of $C$. connivens is mainly restricted to western Estonia and only few findings have been found in Gulf of Finland (Fig. 1). C. connivens has been recorded in single locations in the 1960s in Estonian coastal waters, following the continuous enlargement of distribution area since 2005. Since 1995, the frequency of non-native C. connivens among findings of other charophytes has been $8-15 \%$ (Fig. 2).

Distribution of both studied macrozoobenthos species covers whole Estonian coastline. However, the current distribution area of native $G$. salinus is remarkably wider compared to G. tigrinus. $G$ salinus occurs also in offshore areas while $G$. tigrinus was mainly found in sheltered bays or near coastline (Fig. 1). G. tigrinus has showed significant occupation success in the region since first finding in 2003, currently the non-native species form up to $21 \%$ of findings of gammarids (Fig. 3). In addition to rapid increase of distribution range, $G$. tigrinus is dominant species among gammarids in many areas (Fig. 4).

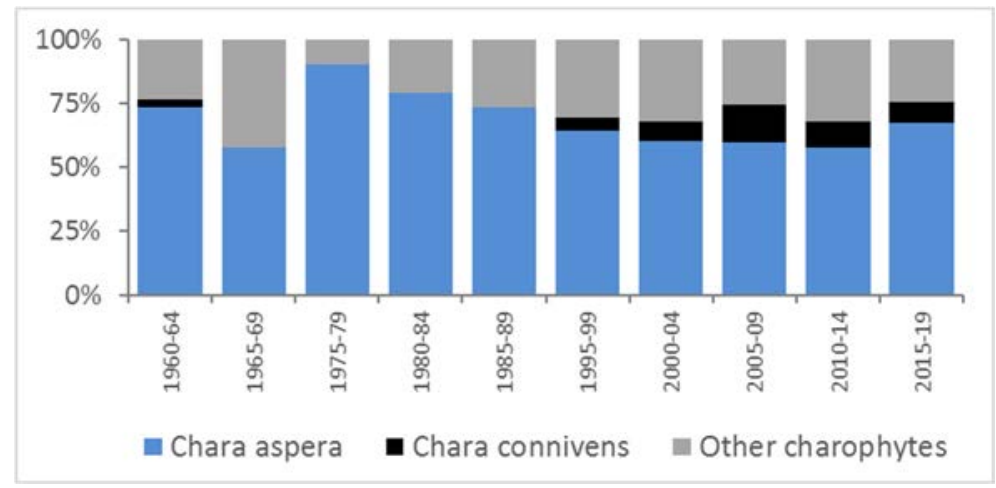

Figure 2: Frequency of occurrence of charophytes based on long-term (1960-2019) data in the Estonian coastal area

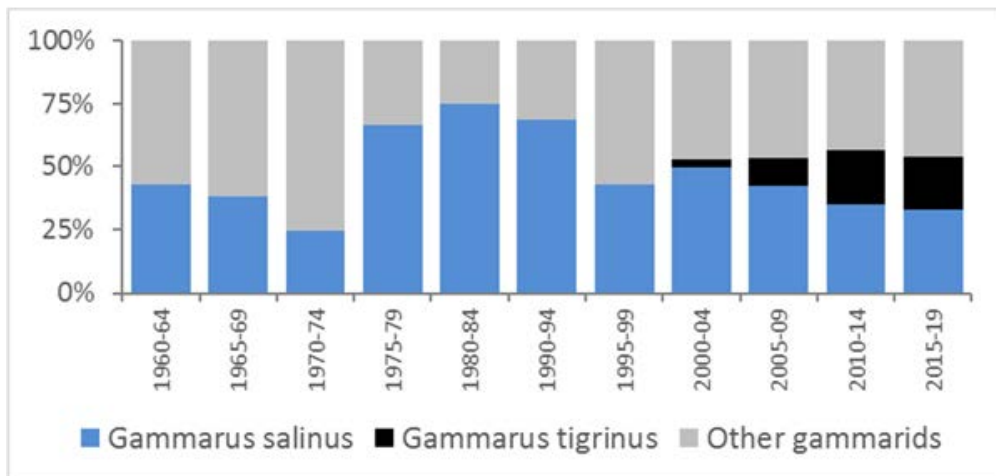

Figure 3: Frequency of occurrence of gammarids based on long-term (1960-2019) data in the Estonian coastal area. 


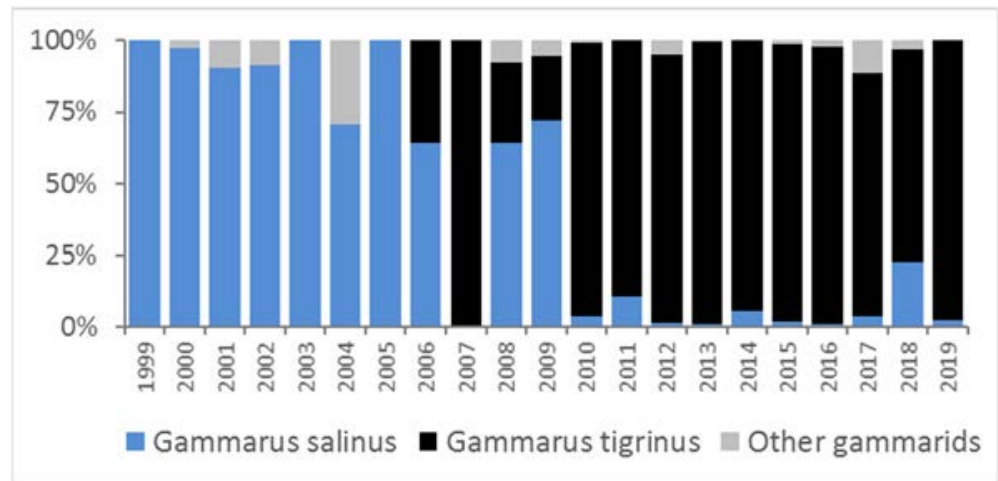

Figure 4: Proportion of abundance of gammarids based on long-term (1999-2019) data in Pärnu Bay.

\subsection{Future distribution of species}

The future climate change influenced the distribution of all the studied species in the NE Baltic Sea. The climate change scenario indicated that possibly both Chara species increase their range (Fig. 5). Distribution area of the non-native C. connivens was predicted to double while native C. aspera was predicted to increase $18 \%$. The distribution of C. connivens increased notably in several regions of the study area. Contrastingly, a significant decrease of $65 \%$ of distribution area of the native G. salinus was predicted. The biggest loss was predicted to take place in Western Estonia Archipelago Sea and in the Gulf of Riga. The distribution of the non-native G. tigrinus was expected to increase $15 \%$. Future increase of G. tigrinus was predicted also in West Estonian Archipelago Sea and in some sheltered bays in the Gulf of Finland.

\section{DISCUSSION}

According to the current data, the studied native benthic species (C. aspera, G. salinuss) are more widely distributed than newcomers. However, the future shifts in temperature, salinity and wave exposure may cause marked changes in distribution of many species. Based on the model predictions, the climate change will cause a significant increase of the distribution area of non-native species compared to native species. Distribution area of $C$. connivens is predicted to doubled and G. tigrinus to increase $15 \%$. Change of environmental conditions also favour the distribution of native charophyte $C$. aspera while $G$. salinus is predicted to lose $65 \%$ of its distribution area (Fig. 5). The largest changes were predicted to take place in relatively shallow and moderately sheltered West Estonian Archipelago Sea, where benthic species diversity is reported to be the highest [34].

Distribution patterns of species are defined by their requirements of environmental conditions. In general, charophytes cannot tolerate rough wave action and high salinities and therefore are more frequent in sheltered to moderately sheltered less saline areas in the Baltic Sea [18], [22]. However, species-specific differences of habitat preferences are detected [35]. While the genus Chara has freshwater origin, the salinity tolerance of the species differs. For example, Chara baltica and Chara canescens cannot tolerate salinity below 1.5-2 PSU while all other genus Chara species occurring in the Estonian coastal sea can grow both in fresh and brackish water [35]. In Estonian coastal sea, C. connivens prefers higher temperatures, greater depth, and lower salinity compared to C. aspera. 


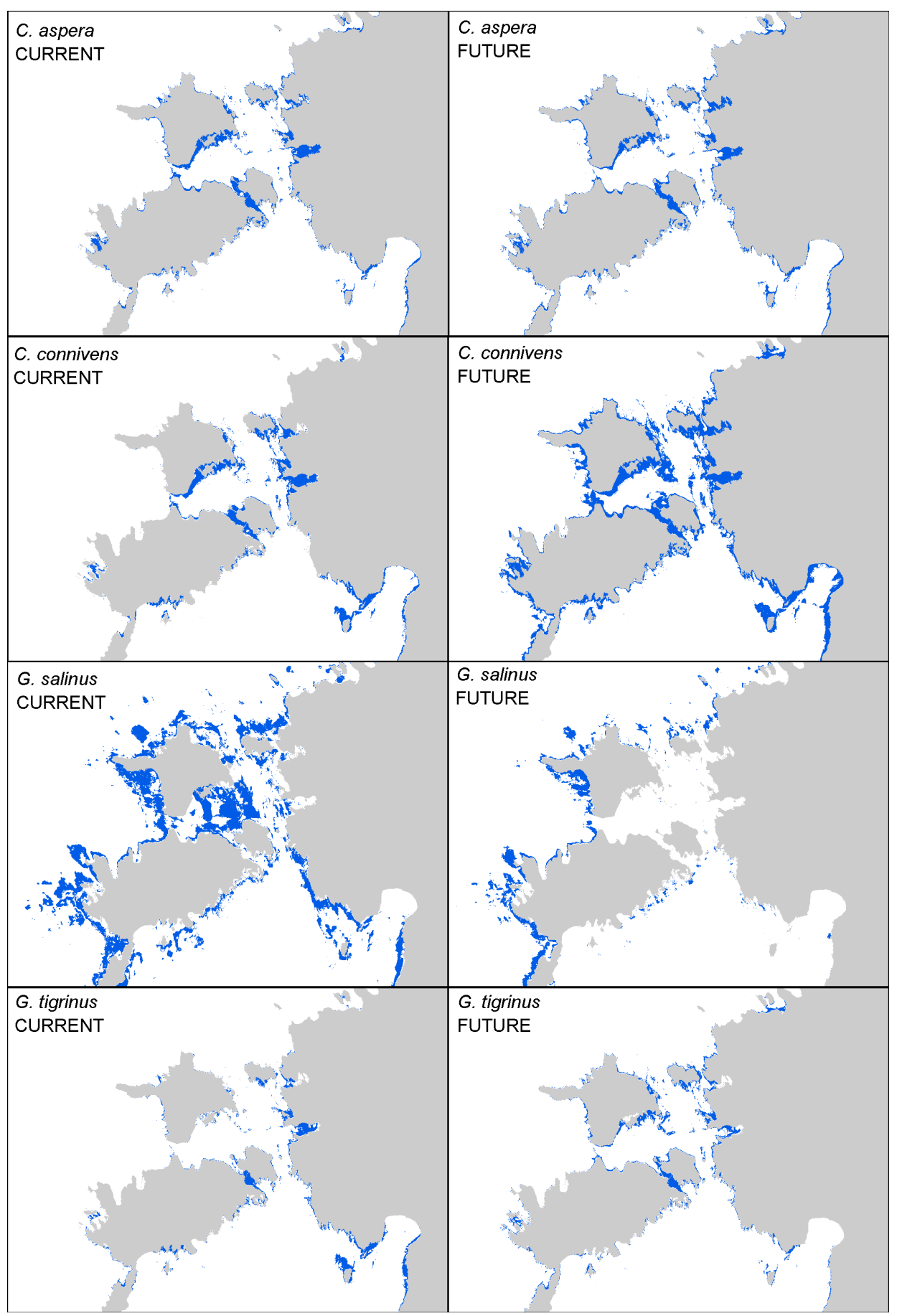

Figure 5: Distribution of native (C. aspera, G. salinus) and non-native species (C. connivens, G. tigrinus) as predicted by RF models for current and future climate scenarios. The western part of the study area is zoomed in for easier comparison. 
Salinity and the temperature are the most important factors determining the distribution of gammarids [36]. Based on the current and previous studies, G. salinus prefers more exposed and deeper areas compared to G. tigrinus [22], [24]. Ongoing climate change is predicted to decrease salinity up to 3.3 unit in Estonian marine areas. This decline will cause a shift of the distribution of marine species toward more saline western areas. Due to the salinity tolerance of $G$. salinus, the future shift in salinity in the study area is predicted to cause the disappearance of the species in West Estonian Archipelago Sea. The same trend is predicted also for important habitat forming macrovegetation species like Furcellaria lumbricalis and Zostera marina [13].

All brackish seas in Europe are subject to intense invasion of non-indigenous species [37]. The wide salinity gradient in brackish water allow for greater range of invasive species to establish suitable areas. The low species richness of the Baltic Sea makes the area especially vulnerable for invasions [14]. Although the breadth of environmental niche space of both non-native species was narrower compared to native species [24], [35], it has not hindered previous or further range expansion of the species in Estonian marine waters. This range expansion is due to the fact that the ongoing climate change in the aquatic environment (e.g. rise of temperature, decrease in salinity) shifts towards more favourable conditions for $C$. connivens and G. tigrinus.

Although the first findings of $C$. connivens in the Baltic Sea were in the southern areas, the species disappeared from these areas for decades [23]. For a long period, the distribution of the species in the Baltic Sea has been registered only in few locations in Sweden and Estonia [18]. Currently, the species is constantly expanding its range and abundance in Estonian coastal sea. New findings have been recorded lately in Finland (2004) and Poland $(2011,2012)$ [20], [38].

Among the recent benthic invaders, G. tigrinus have proven to be the most aggressive in the Baltic Sea [39]. Already two years after the first finding, the species accounted for about $50 \%$ of the total occurrence of gammarids in the south coast of Saaremaa Island [21]. G. tigrinus is more selective about environmental conditions in Estonian waters compared to its native range. Although the species is euryhaline, it is more frequent at salinities $0-5$ and prefers sheltered bays in Estonia [39]. These preferences will lead to increase of distribution area of the species in the future due to climate change.

It has been demonstrated in an experimental study [40] that adult gammarids exert a significant predation pressure on juvenile amphipods. Moreover, the breeding season starts earlier in the invasive G. tigrinus than in local gammarids and the brood size is larger in the invasive species [40]. Thus, the combined effect of predation on juvenile amphipods and large brood production of $G$. tigrinus could be plausible explanations describing increased abundance of G. tigrinus and decrease of local gammarid populations in the north-eastern Baltic Sea. The projected climate change could further facilitate the success of G. tigrinus. Additional to the fact that gammarids are important diet for other amphipod individuals [40], gammarids are also considered as one of the most important nektobenthic herbivores and crucial food choice for various coastal fish species [41], [42]. It has been proven that, for example, the native fish species Gasterosteus aculeatus prefers G. tigrinus as a food source [43], so predicting increased distribution of the species in the future could also support the increase of the certain fish species. However, in general, the predicted summarized loss of the distribution of the both studied gammarid species under the future climate conditions can have a strong negative impact on several fish species who diet contains gammarids.

Predicting future changes is an important tool for risk assessment and management of marine resources. In the future, changing thermohaline conditions, increased storm wave height and turbidity may cause changes in compositions and spatial patterns of bottom 
communities [9], [44]. This study predicts species-specific responses to climatic changes and gives an opportunity for better planning of further monitoring activities, environmental legislation and coastal zone management.

\section{CONCLUSION}

Our monitoring and modelling studies have shown that currently the studied native species, charophyte Chara aspera and gammarid amphipod Gammarus salinus, are more widely distributed than their non-native congenerics. However, decreasing salinity, increasing temperature and changes in wave exposure will have specific effects on all marine species. Most importantly, the predicted climate change will cause a significant increase in the distribution area of non-native species (Chara connivens, Gammarus tigrinus), which would largely occur on account of native species. The largest, adverse changes were predicted to take place in the relatively shallow and moderately sheltered West Estonian Archipelago Sea, which is currently a hot-spot of benthic biodiversity.

\section{ACKNOWLEDGEMENT}

This study was supported by the Estonian Science Foundation through grant PUT1439.

\section{REFERENCES}

[1] Intergovernmental Panel on Climate Change (IPCC), Fifth Assessment Report (AR5), 2014. www.ipcc.ch/report/ar5/. Accessed on: 8 Mar. 2020.

[2] Doney, S.C. et al., Climate change impacts on marine ecosystems. Annual Review of Marine Science, 4(1), pp. 11-37, 2012.

[3] Hoegh-Guldberg, O. \& Bruno, J.F., The impact of climate change on the World's marine ecosystems. Science, 328, pp. 1523-1528, 2010.

[4] Meier, H.E.M. et al., Future projections of record-breaking sea surface temperature and cyanobacteria bloom events in the Baltic Sea. Ambio, 48, pp. 1362-1376, 2019.

[5] Dippner, J.W., Fründt, B. \& Hammer, C., Lake or sea? The unknown future of central Baltic Sea herring. Frontiers in Ecology and Evolution, 7(143), 2019.

[6] The BACC II Author Team, Second Assessment of Climate Change for the Baltic Sea Basin. Regional Climate Studies, Springer: Cham, 501 pp., 2015.

[7] Suursaar, Ü., Kullas, T., Kovtun, A., Torn, K. \& Aps, R., Climate change induced decadal variations in hydrodynamic conditions and their influence on benthic habitats of the Estonian coastal sea. WIT Transactions on Ecology and the Environment, Vol. 148, WIT Press: Southampton and Boston: pp. 427-438, 2011.

[8] HELCOM 2013, Climate change in the Baltic Sea area: HELCOM thematic assessment in 2013. Baltic Sea Environment Proceedings, 137, 2013.

[9] Takolander, A., Cabeza, M. \& Leskinen, E., Climate change can cause complex responses in Baltic Sea macroalgae: A systematic review. Journal of Sea Research, 123, pp. 16-29, 2017.

[10] Olsson, J., Bergström, L. \& Gårdmark, A., Top-down regulation, climate and multidecadal changes in coastal zoobenthos communities in two Baltic Sea areas. PLoS ONE, 8(5), e64767, 2013.

[11] Snoeijs, P., Marine and brackish waters. Swedish Plant Geography, eds. P. Snoeijs \& M. Diekmann, Opulus Press: Uppsala, pp. 187-212, 1999.

[12] Jonsson, P.R. et al., High climate velocity and population fragmentation may constrain climate-driven range shift of the key habitat former Fucus vesiculosus. Biodiversity Research, 24, pp. 892-905, 2018. 
[13] Torn, K., Peterson, A. \& Herkül, K., Predicting the impact of climate change on the distribution of the key habitat-forming species in the NE Baltic Sea. Journal of Coastal Research, 95, 2020. In print.

[14] Paavola, M., Olenin, S. \& Leppäkoski, E., Are invasive species most successful in habitats of low native species richness across European brackish water seas? Estuarine Coastal and Shelf Science, 64(4), pp. 738-750, 2005.

[15] Holopainen, R. et al., Impact of changing climate on the non-indigenous invertebrates in the northern Baltic Sea by end of the twenty-first century. Biological Invasions, 18, pp. 3015-3030, 2016.

[16] Torn, K., Peterson, A., Herkül, K. \& Suursaar, Ü., Effects of climate change on the occurrence of charophytes and angiosperms in a brackish environment. Webbia: Journal of Plant Taxonomy and Geography, 74(1), pp. 167-177, 2019.

[17] Jänes, H., Herkül, K. \& Kotta, J., Environmental niche separation between native and non-native benthic invertebrate species: Case study of the northern Baltic Sea. Marine Environmental Research, 131, pp. 123-133, 2017.

[18] Schubert, H. \& Blindow, I. (eds), Charophytes of the Baltic Sea, Koltz Scientific Books: Köningstein/Taunus, 2003.

[19] Chaumot, A., Geffard, O., Armengaud, J. \& Maltby, L., Gammarids as reference species for freshwater monitoring. Aquatic Ecotoxicology, eds. C. Amiard-Triquet, J.-C. Amiard \& C. Mouneyrac, Academic Press, 2015.

[20] Luther, H., Chara connivens in the Baltic Sea area. Annales Botanici Fennici, 16, pp. 141-150, 1979.

[21] Brzeska, P., Woźnicka, A., Pełechaty, M. \& Blindow, I., New records of Chara connivens P. Salzmann ex A. Braun 1835: An extremely rare and protected species in polish brackish waters. Acta Societatis Botanicorum Poloniae, 84(1), pp. 143-146, 2015.

[22] Reisalu, G., Kotta, J., Herkül, K. \& Kotta, I., The invasive amphipod Gammarus tigrinus Sexton, 1939 displaces native gammarid amphipod from sheltered macrophyte habitats of the Gulf of Riga. Aquatic Invasions, 11(1), pp. 45-54, 2016.

[23] Arbeitsgruppe Characeen Deutschlands, Armleuchter-algen Die Characeen Deutschlands Arbeitsgruppe Characeen Deutschlands, Springer-Verlag: Berlin, 2016.

[24] Herkül, K., Lauringson, V. \& Kotta, J., Specialization among amphipods: The invasive Gammarus tigrinus has narrower niche space compared to native gammarids. Ecosphere, 7(6), e01306, 2016.

[25] Bousfield, E., Freshwater crustaceans of glaciated North America. Canadian Field Naturalist, 72(2), pp. 55-113, 1958.

[26] Budd, G., A gammarid shrimp (Gammarus salinus). Marine Life Information Network, Plymouth,. www.marlin.ac.uk/species/detail/1699. Accessed on: 17 Mar. 2020.

[27] Isæus, M., Factors Structuring Fucus Communities at Open and Complex Coastlines in the Baltic Sea, Stockholm University: Stockholm, 2004.

[28] Meier, H.E.M. et al., Modeling the combined impact of changing climate and changing nutrient loads on the Baltic Sea environment in an ensemble of transient simulations for 1961-2099. Climate Dynamics, 39, pp. 2421-2441, 2012.

[29] Roeckner, E. et al., Sensitivity of simulated climate to horizontal and vertical resolution in the ECHAM5 atmosphere model. Journal of Climate, 19, pp. 3771-3791, 2006. 
[30] Meier, H.E.M., Döscher, R. \& Faxen, T., A multiprocessor coupled ice-ocean model for the Baltic Sea: Application to salt inflow. Journal of Geophysical Research Oceans, 108, p. 3273, 2003. DOI: 10.1029/2000JC000521.

[31] Nakićenović, N. et al., Special Report on Emissions Scenarios: A Special Report of Working Group III of the Intergovernmental Panel on Climate Change, Cambridge University Press: Cambridge, 2000.

[32] R Core Team, R: A Language and Environment for Statistical Computing, $\mathrm{R}$ Foundation for Statistical Computing: Vienna, 2019.

[33] Breiman, L., Cutler, A., Liaw, A. \& Wiener, M., randomForest: Breiman and Cutler's random forests for classification and regression. $\mathrm{R}$ package version 4.6-14. http://cran.r-project.org/web/packages/randomForest/. Accessed on: 20 Mar. 2020.

[34] Peterson, A., Herkül, K. \& Torn, K., Modeling coastal benthic biodiversity using georeferenced environmental data: Mapping present and predicting future changes. Journal of Coastal Research, 85, pp. 376-380, 2018.

[35] Herkül, K., Torn, K. \& Möller, T., The environmental niche separation between charophytes and angiosperms in the northern Baltic Sea. Botany Letters, 165, pp. 115-127, 2018.

[36] Bulnheim, H.P., Comparative studies on the physiological ecology of five euryhaline Gammarus species. Oecologia, 44, pp. 80-86, 1979.

[37] Leppäkoski, E., Gollasch, S. \& Olenin, S. (eds), Invasive Aquatic Species of Europe. Distribution Impacts and Management, Kluwer Academic Publishers: Dordrecht, 2002.

[38] Apelgren, K., Snickars, M. \& Mattila, J., Chara connivens Saltzm. Ex. A. Braun 1835 found in the Åland archipelago: A new species to Finland. Memoranda - Societatis pro Fauna et Flora Fennica, 80(1), pp. 11-13, 2004.

[39] Kotta, J. et al., Is a rapid expansion of the invasive amphipod Gammarus tigrinus Sexton, 1939 associated with its niche selection: A case study in the Gulf of Finland, the Baltic Sea. Aquatic Invasions, 8(3), pp. 319-332, 2013.

[40] Jänes, H., Kotta, J. \& Herkül, K., High fecundity and predation pressure of the invasive Gammarus tigrinus cause decline of indigenous gammarids. Estuarine, Coastal and Shelf Science, 165, pp. 185-189, 2015.

[41] Kotta, J., Orav-Kotta, H. \& Herkül, K., Separate and combined effects of habitatspecific fish predation on the survival of invasive and native gammarids. Journal of Sea Research, 64, pp. 369-372, 2010.

[42] Nelson, W.G., Experimental studies of decapod and fish predation on seagrass macrobenthos. Marine Ecology Progress Series, 5, pp. 141-149, 1981.

[43] MacNeil, C., Dick, J.T.A. \& Elwood, R.W., The dynamics of predation on Gammarus spp. (Crustacea: Amphipoda.) Biological Reviews, 74, pp. 375-395, 1999.

[44] Kovtun, A., Torn, K., Martin, G., Kullas, T., Kotta, J. \& Suursaar, Ü., Influence of abiotic environmental conditions on spatial distribution of charophytes in the coastal waters of West Estonian Archipelago, Baltic Sea. Journal of Coastal Research, 64, pp. 412-416, 2011. 